\title{
Effect of lons Released and pH of Two Glass Ionomer Cements in Human Gingival Fibroblasts
}

\section{Efecto de la liberación de iones y pH de dos cementos de ionómero de vidrio en fibroblastos gingivales humanos}

Alejandro L. Vega-Jiménez DDS, MSc, PhD¹; Ana G. Rodríguez-Hernández DDS, MSc, PhD²; María Cristina Piña-Barba PhD³; Javier Ambrosio-Hernández $\mathrm{PhD}^{4}$

1. Laboratory of Tissue Bioengineering. Faculty of Dentistry, Division of Postgraduate Studies and Dental Research. National Autonomous University of Mexico, Mexico.

2. CONACyT Research Fellow at Center of Nanoscience and Nanotechnology. National Autonomous University of Mexico, Ensenada, Baja California, Mexico.

3. Department of Ceramic Materials. Institute of Materials Research. National Autonomous University of Mexico, Mexico. 4. Department of Microbiology and Parasitology. Faculty of Medicine, National Autonomous University of Mexico, Mexico.

Correspondence to: Dr. Alejandro L. Vega-Jiménez - dr.vegalex@gmail.com

Received: 14-IX-2018

Accepted: 9-X-2018

Published Online First: 16-X-2018

DOl: https://doi.org/10.15517/ijds.v0i0.34886

\section{ABSTRACT}

Conventional glass ionomer cements are used as dental provisional restorative materials, which present several advantages such as adhesion to the tooth mineral phase among others. On the other hand, the knowledge about biological property of glass ionomers shows various approaches and results. In this work, it was studied the in vitro biological response of human gingival fibroblasts in contact with commercial cements of glass ionomer: Mirafil ${ }^{\circledR}$ and longlass $®$ and with their extracts, according to ISO 10993. The extracts of the cements, in which the cells were cultured, were adjusted at different concentrations ranging $0.1 \%$ to $100 \%$. The cellular metabolic activity of gingival fibroblasts was measured using the Alamar Blue ${ }^{\circledR}$ reagent. The results showed a significant effect on the cellular metabolic activity correlated with the concentration of liberated ions $\left(\mathrm{Al}^{3}+\right.$ and $\left.\mathrm{Ca}^{2}+\right)$ for both ionomers, as well as the $\mathrm{pH}$ variations of the culture media. This could mean that the cellular metabolic activity is substantially influenced by ions and $\mathrm{pH}$ of the cell culture.

\section{KEYWORDS}

Glass ionomer cement; Dental cement; pH; Ions; Cytotoxicity test; Cell culture; Cell viability. 


\section{RESUMEN}

Los cementos de ionómero de vidrio convencionales se utilizan como materiales de restauración provisional para uso dental, los cuales presentan varias ventajas como la adhesión a la fase mineral de los dientes. Por otro lado, las propiedades biológicas de los ionómeros de vidrio muestran diversos enfoques y resultados. En éste trabajo se estudió la respuesta biológica in vitro de fibroblastos gingivales humanos en contacto con cementos comerciales de ionómero de vidrio: Mirafilß e longlass $\circledast$ y con sus respectivos extractos según la norma ISO 10993. Los extractos de los cementos en los que se cultivaron las células estaban en diferentes concentraciones: de $0.1 \%$ a 100\%. La actividad metabólica celular se midió usando el reactivo Alamar Blueß. Los resultados mostraron un efecto significativo sobre la actividad metabólica celular correlacionada con la concentración de iones liberados $\left(\mathrm{Al}^{3}+\right.$ y $\left.\mathrm{Ca}^{2}+\right)$ para ambos ionómeros, así como las variaciones de pH de los medios de cultivo. Ello podria explicar la influencia por los iones y el pH del cultivo celular en la actividad metabólica celular.

\section{PALABRAS CLAVE}

Cemento de ionómero de vidrio; Cemento dental; pH; Iones; Ensayo de citotoxicidad; Viabilidad celular.

\section{INTRODUCTION}

Convencional glass ionomer cement (GIC) consist of an aqueous polyalkenoic acid (polyacrilic acid), which react with powder of calcium fluoro alumino silicate glass under acid-base reaction (1). GICs have several important properties such as: 1) fluoride release, which confers antibacterial effect and enhance hardness of mineral phase as dental enamel as well dentine (2); 2) thermal expansion coefficient and module of elasticity similar to the dentin (3) and 3) the physical and chemical adhesion of GIC on both enamel and dentin is physical and chemical (4). These properties have considered that this cement one of the most used materials in the dental practice. The cytotoxic effects of GIC in direct contact with fibroblasts have been documented in some cell culture studies (5-9). In this sense, released metal ions have been suggested as a cause of cytotoxicity, which are liberated from GIC in its initial setting phase. On the other hand, particles such as alumina had been identified in cultivated cells on surface of set glass ionomers, where they had no visible detrimental effect $(10,11)$. Furthermore, $\mathrm{pH}$ reduction during cements setting and maturing process has been suggested too as a cause of cyto and neurotoxicity, which might be related with the presence of acrylic acid in GICs (12). Is important to mention that studies on biocompatibility need to be carried out during evaluation of dental materials, since this is a major requirement, especially when they have been considered for implantation (1214) and adapted for use in the implant abutment cement-retained crown (CRC) technique for the intimate contact with gingiva (15). Hence, the aim of this study was to evaluate the in vitro biological response of human gingival fibroblasts incubated with two conventional glass ionomer cements by Alamar Blue $®$ reagent using two different tests; direct and extract contacts. Finally, the study was carried out in order to perform an analysis of the influence of both $\mathrm{pH}$ variations and ions released in the viability and cytotoxicity. 
MATERIALS AND METHODS

\section{GLASS IONOMER SAMPLES}

Two commercial GICs were used: Ionglass $®$ (Viarden SA de CV, Mexico) and Mirafill (Faprodmir, Germany). Samples were prepared according to powder/liquid ratio mixture indicated by each manufacturer; then samples were placed under temperature $\left(37 \pm 1^{\circ} \mathrm{C}\right)$ and humidity $(90 \%)$ controlled for one hour according to ANSI/ADA Standard No. 96. The samples were immersed in deionized water and stored in an oven at $37{ }^{\circ} \mathrm{C}$ for 24 hours. Previous cell culture experiments, all samples were sterilized under UV radiation inside of a laminar flow cabinet for $40 \mathrm{~min}$. The surfaces of materials were observed by Scanning Electron Microscopy (SEM) JEOL 5600 LV with secondary electrons at $20 \mathrm{keV}$.

\section{DETECTION OF RELEASED IONS FROM GICS AND PH MEASUREMENTS IN DMEM}

The elements released in DMEM from GIC samples $\left(\mathrm{As}^{5}+, \mathrm{Pb}^{2}+, \mathrm{Al}^{3}+, \mathrm{Ca}^{2}+, \mathrm{Na}+, \mathrm{K}+\right)$ were measured by Atomic Absorption Spectroscope (AAS 3100 Perkin Elmer ${ }^{\circledR}$ ). Previously, $4 \mathrm{~mL}$ of each extract were digested in Teflon ${ }^{\circledR}$ reactors with $1 \mathrm{~mL}$ of $\mathrm{HNO}$ and $1.25 \mathrm{~mL}$ of $\mathrm{HCl}$ at $90^{\circ} \mathrm{C}$ for $8 \mathrm{~h}$. Therefore, $0.25 \mathrm{~mL}$ of LaO3 was added and solutions were gauged until final volume of $25 \mathrm{~mL}$. Whereas, $\mathrm{pH}$ variations in culture media were monitored at 12, 24, 36, 48 and 72 hours trough the use of a pHmeter (pH HANNA $₫ 213$ ).

\section{CELL CULTURE ASSAYS}

Previous to material-cell experiments, human gingival fibroblasts [15] were grown and maintained in Dulbecco's Modified Eagle's Medium (DMEM GIBCO $®$ ), supplemented with $10 \%$ Fetal Bovine Serum (FBS GIBCO $($ ), 8mM L-glutamine (GIBCO $尺$ ) and penicillin $(50,000$ units $/ \mathrm{mL}) /$ streptomycin $(50 \mathrm{mg} / \mathrm{mL})(\mathrm{GIBCO} \otimes)$ at $37^{\circ} \mathrm{C}$ and $5 \% \mathrm{C02}$. For each sort of experiment 40,000 fibroblasts per well were seeded in 24 multiwell culture plates (Nunc ${ }^{\circledR}$ ) and incubated during 4 hours until cells spreading. Cell-materials experiments were performed with extracts of GICs in culture media as well as cell material direct as is indicated below. In both experiments, cell viability was assessed by monitoring their metabolic activity using Alamar Blue $®(A B r)$ (Invitrogen $\AA)$, measurements were collected at $570 \mathrm{~nm}$ wavelength in a spectrophotometer Benchmark Plus (BI0-RAD $\otimes$ ) at $600 \mathrm{~nm}$ wavelength of reference).

\section{CELL-EXTRACT MATERIAL ASSAY}

Extracts were obtained from GIC Mirafill $囚$ as well as longlass ${ }^{\circledR}$ after 72 hours of incubation at $37^{\circ} \mathrm{C}$ in supplemented DMEM. 4 discs of $15 \mathrm{~mm}$ diameter and $4.5 \mathrm{~mm}$ thickness where incubated in $11 \mathrm{~mL}$ of culture media, according to ratio $3 \mathrm{~mm} 2 / \mathrm{mL}$ established into standard ISO 109935 guidelines. Under these conditions, we defined the media recovered as initial extract (100\%) that contained the total amount of released ions. Finally different dilutions were prepared from initial extract: $50 \%, 10 \%, 1 \%$ and $0.1 \%$. Chlorine (Cl) was used as positive control of cytotoxicity, whereas supplemented DMEM was the negative control. Cells where incubated with GICs extract and controls for 12 hours at $37^{\circ} \mathrm{C}$ and $5 \%$ CO2 in 24 multiwell plate. At the same time, different amount of cells (since 300 until 50,000) were seeded in order to obtain a standard curve (relation between number of cells and absorbance). Then $10 \%$ of $\mathrm{ABr}$ was added to all cell cultures, according to $O^{\prime}$ Brien procedure (13), and plates were again incubated for 12 hours. $100 \mu \mathrm{L}$ from each well were placed into 96 multiwell plate and absorbance was measured. At the end of the incubation, fibroblast morphology was observed using a light conventional microscopy with an inverted microscope NIKON $尺$ TS100. Images were taken with a digital camera (DS-Fi1-U2, NIKON@ and processed with software NIS Elements F® V 3.0 . 


\section{DIRECT CONTACT CELL-MATERIAL ASSAY}

For this experiment, GIC and controls disc of $4 \mathrm{~mm}$ diameter and $6 \mathrm{~mm}$ thickness (Alumina as negative control and PVC as positive control of cytotoxicity) were placed directly in contact with cells into 24 multiwell culture plate, according to standard ISO 10993-5 guidelines. $10 \%$ of $\mathrm{ABr}$ was added to each well and cells were incubated during 72 hours at $37^{\circ} \mathrm{C}$ and $5 \% \mathrm{CO} 2$. Measurements of absorbance were carried out at 12,24,36,48 and 72 hours of incubation by removing $100 \mu \mathrm{L}$ of supernatant and placing them into a 96 multiwell plate.

\section{STATISTICAL ANALYSIS}

Statistical analysis was performed by analysis of variance (ANOVA) and Tukey was applied as multiple range test post hoc using software Origin 6.1, with a significance level of $p=0.05$. The analyses were performed with the results of direct cell-material contact and extract of three independent experiments.

\section{RESULTS}

\section{SEM IMAGES OF GLASS IONOMER SAMPLES}

SEM micrographs of GICs before cell culture assay are shown in Fig.1. Both surfaces presented cracks, which were more in quantity and extension on Mirafill ${ }^{\circledR}$ (Fig.1-A) compared to longlass ${ }^{\circledR}$ (Fig.1-C). To the contrary, higher porosity and embedded particles were observed on longlass $\AA$ (Fig.1-B) than Mirafill ${ }^{\circledR}$ surface (Fig.1-D).

RELEASED IONS FROM GICS AND PH MEASUREMENTS IN DMEM

Ions liberated to culture media from both GICs, were presented in table 1 , where just $\mathrm{Al}^{3}+$ and $\mathrm{Ca}^{2}+$ were detected in DMEM after $72 \mathrm{~h}$ of incubation with both materials, according to standard ISO 10993 guidelines. Presence of $\mathrm{Al}^{3}+$ was just found in longlass ${ }^{\circledR}$; whereas $\mathrm{Ca}^{2}+$ was detected in both ClGs, presenting a higher concentration in Mirafill ${ }^{\circledR}$. On the other hand, pH variations due to presence of GICs in culture media are shown in table 2. In the beginning, the culture media had a neutral $\mathrm{pH}$, which decrease slightly from $7.40 \pm 0.02$ until 7.2 \pm 0.1 for Mirafill $\circledast$ CIG after 36 hours of immersion in DMEM; while longlass ${ }^{\circledR}$ presented a more sudden decrease (from $7.40 \pm 0.02$ to $6.7 \pm 0.1$ ) for the same immersion time. Subsequently in both cases, pH remains constant in the time.

\section{CELL CULTURE ASSAYS}

\section{EFFECT OF RELEASED IONS} ON GINGIVAL FIBROBLASTS

The results of cell cytotoxicity and their relation with both GIC extract concentration are presented in Table 1 and plotted in Figure 2. As can see in this figure, there is an inversely proportional response between the number of viable cells and the extract concentration. The negative control presented a maximum number of viable cells (represented as black bar) which drop abruptly after just an extract dilution of $0.1 \%$. Even this decrement was observed for both materials, longlass $®$ presented a higher cytotoxic effect compared to Mirafill $\circledast$ with a cell viability of $39 \%$ (20581 \pm 68 cells) versus $68 \%$ (36206 \pm 94 cells) respectively.

Following dilutions presented a continuous decrease on number of viable cells, where longlass $\AA$ maintained a higher cytotoxicity compared to Mirafill $\circledast$. Finallly, positive cytotoxic control presented a minimum number of viable cells (189 \pm 56$)$. Statistical analysis by factorial ANOVA followed by Tukey test; showed significant differences between Mirafill@ and longlass ${ }^{\circ}$. Furthemore, both GICs at all concentrations, presented significant differences $(p<0.05)$ with the negative control group.

At the same time, variation of ions concentration $\left(\mathrm{Ca}^{2}+\right.$ and $\left.\mathrm{Al}^{3}+\right)$ and $\mathrm{pH}$ for different 
GIC extract dilutions are shown in figure 3. These dates were obtained from initial and final value of each measurement and applying the rule of mixtures, the intermediate points where obtained. In the case of Mirafill $\circledast$ just $\mathrm{Ca}^{2}+$ was detected, whilst longlass $®$ liberated both $\mathrm{Ca}+2$ and $\mathrm{Al}+3$ (Fig.3-A). Whereas pH variations of culture medium presented a lower pH values of longlass $®$ compared to Mirafill $\circledast$ (Fig.3-B).

\section{DIRECT CONTACT CELL-MATERIAL ASSAY}

Results of cell-material interaction with both GICs and controls are shown in Figure 4. In the image is possible to observe the well defined cell culture trend for each sort of sample. During the cell culture time, the cells were growing in a similar tendency, reaching a maximum between 30 to $50 \mathrm{~h}$.

The statistical analysis, showed that when cells were cultured with alumina was practically identical to Tissue-culture treated polystyrene
(TPS) measurements during all incubation time and no significant differences were observed ( $p>0.05$ ). While GICs results are presented almost the same tendency and measurement without significant differences ( $p>0.05$ ) between them since $24 \mathrm{~h}$ until $72 \mathrm{~h}$, but at $12 \mathrm{~h}$ of incubation significant difference $(p<0.05)$ was observed, because cells in contact to Mirafill $@$ presented a few decrement in its absorbance. Furthermore, both GICs presented significant differences vs alumina at 12, 24 and $36 \mathrm{~h}$ of incubation. Whereas, PVC results showed the lowest absorbance results compared to others $(p<0.05)$

In order to associate the effect of $\mathrm{pH}$ variation in cell viability during incubation, data were plotted versus absorbance for both glass ionomers (Figure 5). Results are showed that cell viability in both cases appear have not be affected by $\mathrm{pH}$ variations, because of cells viability was not compromised in presence neither longlass $₫$ as is shown in Fig. 5-A (even pH decrease until 6.5), nor Mirafill $®$ (Fig. 5-B).

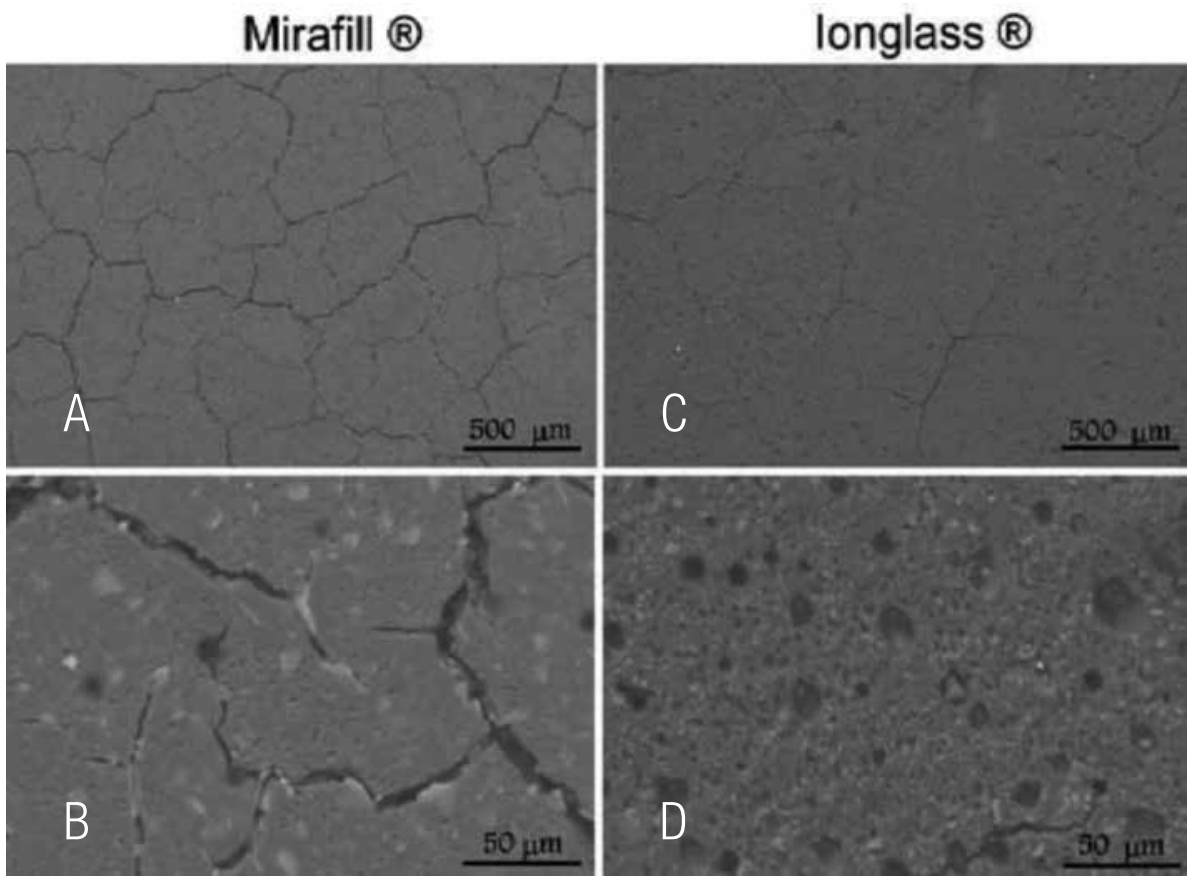

Figure 1. SEM images from Mirafill $(A$ and $B)$ and longlass $®(C$ and $D)$. The presence of cracks was more evident in Mirafill $®$, whereas longlass $₫$ presented a more porous surface. 
Table 1. The absorbance, the cell count and the $\mathrm{Ca}^{2}+$ and $\mathrm{Al}^{3}+$ concentrations measured in the culture media for the different concentrations of the extract are shown.

\begin{tabular}{|c|c|c|c|c|}
\hline $\begin{array}{c}\text { Extrat } \\
\text { concentration } \\
(\%) \\
\end{array}$ & $\begin{array}{c}\text { Absorbance } \\
(570 \mathrm{~nm})\end{array}$ & NO.Cells & $\begin{array}{c}\mathrm{Ca}^{2}+ \\
\text { concentration } \\
(\mu \mathrm{g} / \mathrm{mL})\end{array}$ & $\begin{array}{c}\mathrm{Al}^{3}+ \\
\text { concentration } \\
(\mu \mathrm{g} / \mathrm{mL})\end{array}$ \\
\hline \multicolumn{5}{|c|}{ Ionglass $®$} \\
\hline 100 & $0.264 \pm 0.04$ & $4726 \pm 98$ & 67 & 8 \\
\hline 50 & $0.275 \pm 0.02$ & $7560 \pm 67$ & 61 & 4 \\
\hline 10 & $0.295 \pm 0.009$ & $10881 \pm 51$ & 56.2 & 8 \\
\hline 1 & $0.318 \pm 0.002$ & $16803 \pm 47$ & 55.1 & ND \\
\hline 0.1 & $0.329 \pm 0.02$ & $20581 \pm 68$ & ND & ND \\
\hline \multicolumn{5}{|c|}{ Mirafill@ } \\
\hline 100 & $0.271 \pm 0.005$ & $6945 \pm 49$ & 86 & ND \\
\hline 50 & $0.301 \pm 0.001$ & $12243 \pm 45$ & 70.5 & ND \\
\hline 10 & $0.324 \pm 0.003$ & $18673 \pm 83$ & 58.1 & ND \\
\hline 1 & $0.353 \pm 0.04$ & $31913 \pm 109$ & 55.3 & ND \\
\hline 0.1 & $0.359 \pm 0.04$ & $36206 \pm 94$ & ND & ND \\
\hline \multicolumn{5}{|c|}{ Controls } \\
\hline Positive & $0.077 \pm 0.01$ & $189 \pm 56$ & ND & ND \\
\hline Negative & $0.380 \pm 0.004$ & $53312 \pm 48$ & 55 & ND \\
\hline
\end{tabular}

Table 2. Variation of pH during GICs incubation in DMEM for different times. Data represented are the mean and standard deviation of three isolated experiments.

\begin{tabular}{ccccccc}
\hline & \multicolumn{5}{c}{ Time (h) } \\
\cline { 3 - 7 } & & $\mathbf{1 2}$ & $\mathbf{2 4}$ & $\mathbf{3 6}$ & $\mathbf{4 8}$ & $\mathbf{7 2}$ \\
\hline \multirow{2}{*}{$\mathbf{p H}$} & Mirafill & $7.36 \pm 0.02$ & $7.33 \pm 0.02$ & $7.2 \pm 0.01$ & $7.18 \pm 0$ & $7.18 \pm 0$ \\
& Ionglass $®$ & $7.26 \pm 0.02$ & $7.03 \pm 0.02$ & $6.8 \pm 0.2$ & $6.7 \pm 01$ & $6.7 \pm 0.1$ \\
\hline
\end{tabular}




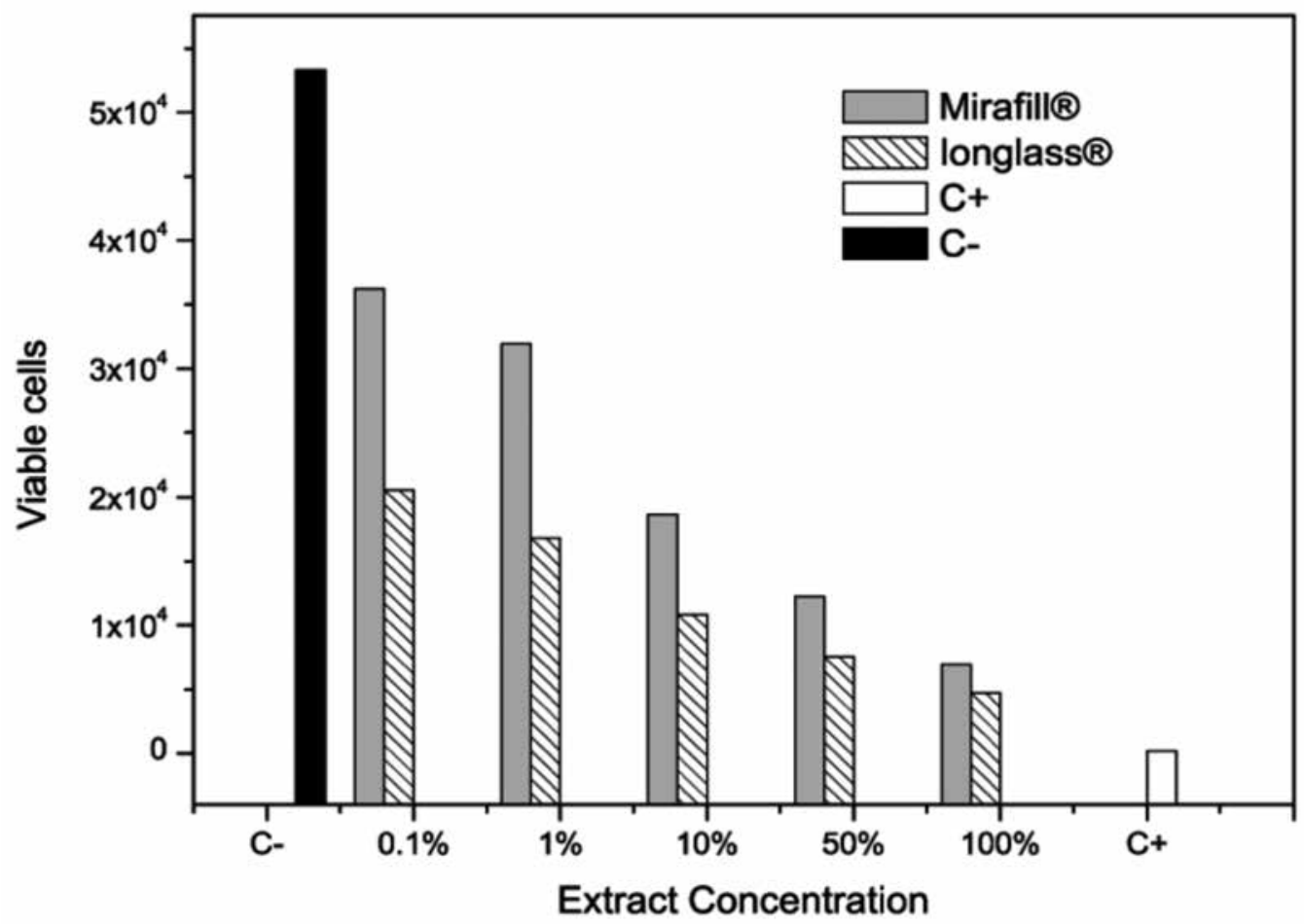

Figure 2. Data of extract concentration and the amount of survivor cells (Data plotted represent the media and the standard deviation of 3 independent assays. For the scale the error bar is not evident), compared to negative (white) and positive (black) control of cytotoxicity.
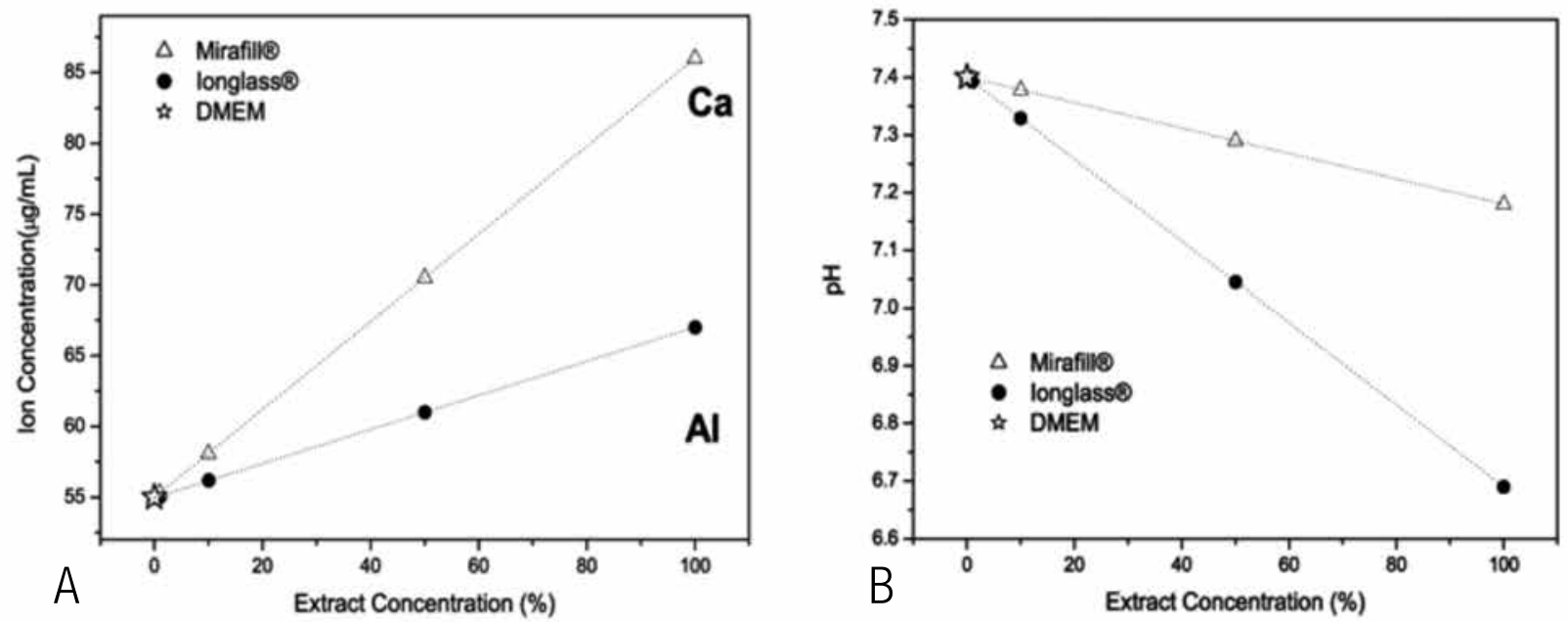

Figure 3. Extract concentration vs the amount of $\mathrm{Ca}^{2}+$ and $\mathrm{Al}^{3}+(\mathrm{A})$ and $\mathrm{vs} \mathrm{pH}(\mathrm{B})$. 


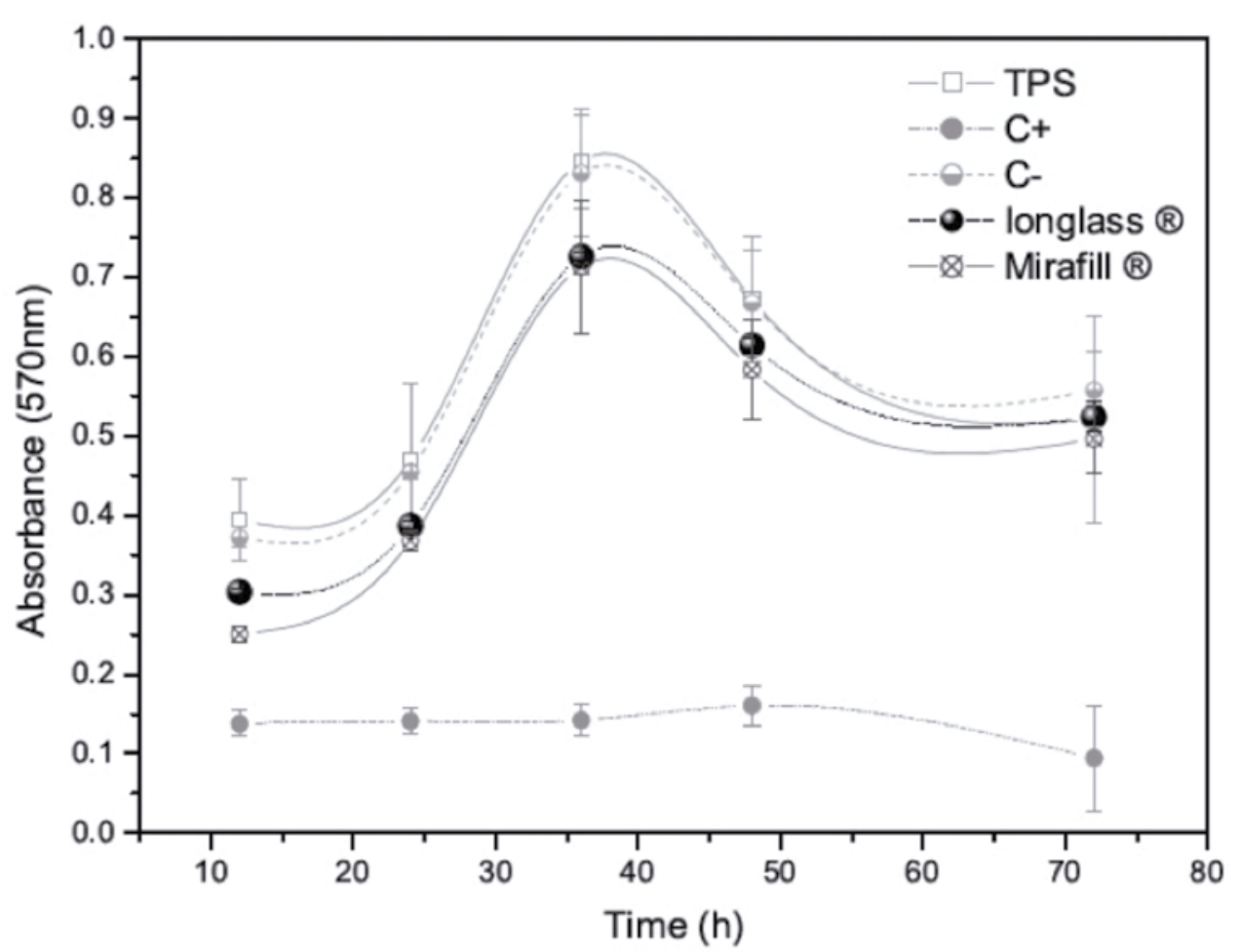

Figure 4. Through the absorbance of the cell culture, by putting the cells in direct contact with the culture plate (TPS), the positive (PVS) and negative (Al203) and the GICs considered, we can measure the cell viability, we can measure the cell viability, which is approximately $88 \%$.
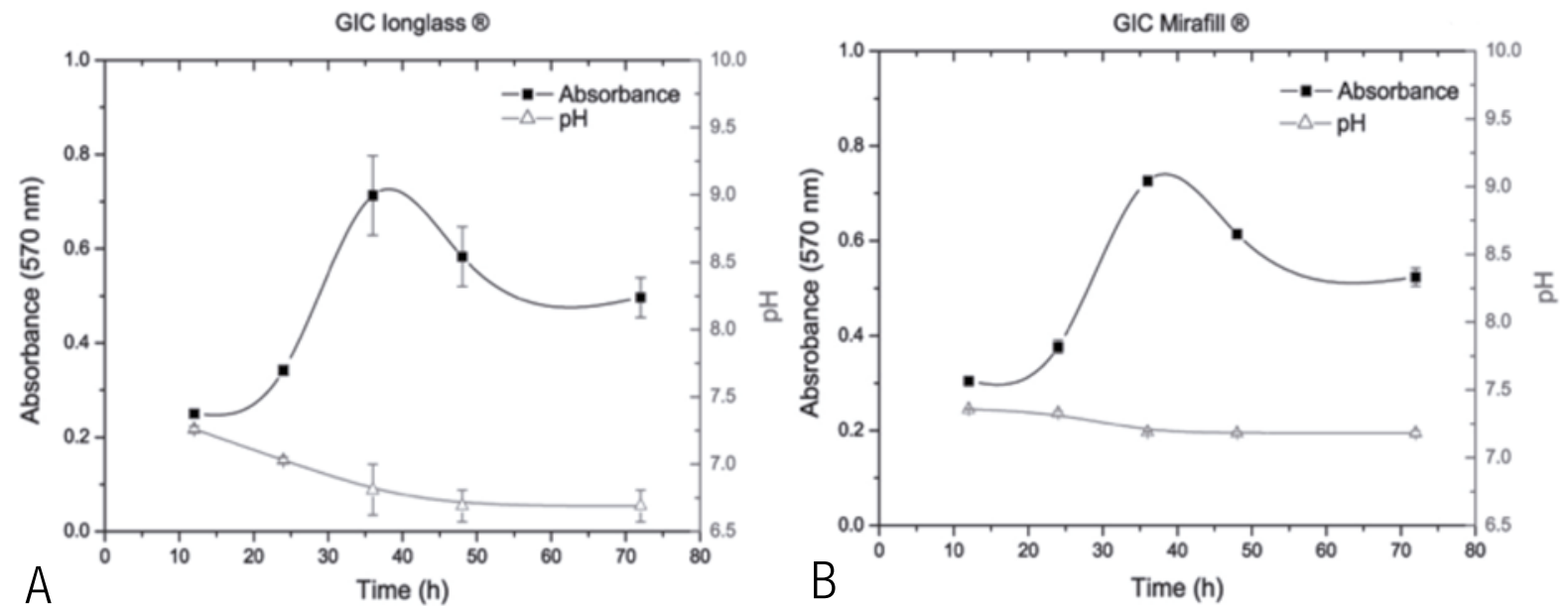

Figure 5. The pH of the cell culture medium, in the ionomers presence remains practically constant over time, as can be seen in graphs $A$ and $B$. The change is a little higher in longlass case. 
DISCUSSION

In this study, the evaluation of cytotoxicity and viability of human gingival fibroblasts in presence of two conventional glass ionomers, have evidenced two important facts: first, the effect of ion released concentration on cell cytotoxicity; and second, the adaptability of cells to environment, due to fibroblasts viability trend in presence of both GICs, besides variations of $\mathrm{pH}$ in culture media.

With respect to GIC cytotoxicity is important to point out that leachables from glasses ionomers are released during early contact with environment, fact well known due to glass ionomers present high solubility during initial 24h (16). This effect can be observed as well $\mathrm{pH}$ variation of culture medium as the variations in cell viability. Some authors have shown that dental glass ionomers can release some substances, compounds and elements such as non polymerized monomers, polyacid, fluoride (17), $\mathrm{Al}^{3}+(12), \mathrm{Ca}^{2}+$, silica, phosphates $(18,19)$, $\mathrm{Pb}$ and $\mathrm{As}$ (17) that are considered to produce an effect on cell viability (20). However, lead and arsenic were not found in this work.

Nevertheless, variations correlated to $\mathrm{Ca}^{2}+$ and $\mathrm{Al}^{3}+$ concentrations in DMEM seem to be the responsible of cell viability. Fact corroborated in results of both ionomers, which have shown a well defined trend correlated to extract concentration, because of the amount of viable cells decrease when extract concentration increase. Into literature there are some reports about importance of $\mathrm{Ca}^{2}+$ in cellular signalling, cell interactions and cell cycle (21). As we could observe, the variation of this ion had a critical effect in cell viability, due to $\mathrm{Ca}^{2}+$ concentration at $50 \%$ for both ionomers showed a significant difference between cells (higher $\mathrm{Ca}^{2}+$ concentration $=$ more cells); however at $100 \%$ of concentration the difference previously observed, almost have disappeared. These results show clearly the effect of $\mathrm{Ca}^{2}+$ in cell viability which are able to sense these small variations, but did not explain the cytotoxic observed. That effect may be more related to $\mathrm{Al}^{3}+(22)$ and $\mathrm{pH}$ concentration.

In the first case the presence of that ion was

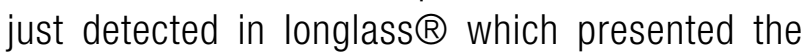
fewer amounts of cells. With respect to $\mathrm{pH}$ and according to rule of mixtures, (Fig.3-B) the $\mathrm{pH}$ variation is more related to cell viability, because the lower pH presented the fewer amount of cells that correspond to longlass $®$ results.

Furthermore, with respect to cells adaptability was well evidenced that initial hours of the cell culture, seems to be crucial in the viability of fibroblasts, because of at this time there were significant differences in the number of viable cells. Subsequently, there appears to be an adaptation of the cells in the presence of the material, as they follow a similar behavior in both the negative control (alumina) and growing under normal in vitro conditions. Although, $\mathrm{pH}$ has been considered a critical factor of cell viability and cytotoxicity (23), our results showed that $\mathrm{pH}$ by itself did not have a determinant effect in cell in vitro growth. This behavior may be explained by a cell modification and adaptation environment process, that allow them continue with their cycle, because of as we observed the numbers of cells are almost equaled, completely independent of $\mathrm{pH}$ variations.

The results obtained allowed to identify that the cytotoxic effect caused for each component and, the cellular adaptability to surrounding environment changes. In the first case, was observed how the concentration of $\mathrm{Al}^{3}+$ and $\mathrm{pH}$ affect survivor cells whereas in the second case, the cell viability results showed the adaptability of cells to variations in culture conditions, due to cells in presence of both ionomers presented the same amount of cells between them, and both are following a similar behavior in contact with $\mathrm{Al}_{2} \mathrm{O}_{3}$ as well as TPS. 
Is important to point of that, even the clinical situation is different due to concentration of elements released, they are diluted in the saliva and the mucosa surface that acts as barrier; in vitro studies provide a significant amount of information that permit to elucidate the response of cell into a toxic environment.

\section{CONCLUSIONS}

According with the results, we can conclude that concentration of products released in the culture medium from the GICs presented a well defined effect in the cellular cytotoxicity. This effect could be originated by the fibroblast metabolic activity that substantially affected by ions and $\mathrm{pH}$ of cell culture, and it has been higher in cells

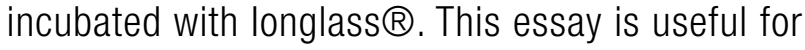
evaluation of threshold limit of toxic products. And with respect to viability results, data showed the adaptability of cells to their environment variations, that can be consider as better assay to evaluate cell cytotoxicity of implantable potentially materials.

\section{FUNDING}

This work was financially supported by Faculty of Dentistry, Institute of Materials Research, Faculty of Medicine (UNAM) and DGAPA-UNAM projects: IT104011, IN201510, IN224316 and IX200610.

\section{CONFLICT OF INTERESTS}

The authors declare no conflicts of interest.

\section{COMPLIANCES WITH ETHICS GUIDELINES}

This article does not contain any studies with human or animal subjects performed by any of the authors.

\section{ACKNOWLEDGEMENTS}

Cells were donated by Dr. Juan Antonio Arreguín-Cano from the Faculty of Dentistry, UNAM. Technical support was provided by Dra. Miriam Marin-Miranda of the Department of Dental Materials at the Dental School from the Faculty of Postgraduate and Studies Zaragoza UNAM, MSc Margarita Linares Zapién and Dr. Federico Barceló-Santana. QFB Maria Guadalupe Espejel performed ion analysis in the Laboratory of Atomic Absorption Spectroscopy at the Postgraduate of the Faculty of Chemistry UNAM. Vega-Jiménez wants to thank to CONACYT (Scholarship No. 330328) and Rodríguez-Hernández wants to thank DGAPA-UNAM for the awarding of the postdoctoral scholarship program.

\section{DISCLAIMER}

The content of the manuscript is solely responsibility of the authors and does not necessarily represents the official views of the National Autonomous University of Mexico.

\section{REFERENCES}

1. Monmaurapoj N., Soodsawang W., Tanodekae W., Channasanoo N. Effect of Glass Preparation on Mechanical Properties of Glass Ionomer Cements. J of Metals, Materials and Minerals 2010; 20: 197-9.

2. Gao W., Smales R. J. Fluoride release/uptake of conventional and resin-modified glass ionomers, and compomers. J Dent 2001; 29: 30-6.

3. Bullard R. H., Leinfelder K. F., Russell C. M. Effect of coefficient of thermal expansion on microleakage. JAm DentAssoc 1998; 116: 871-4.

4. Erickson R. L., Glasspoole E. A. Bonding to tooth structure: a comparison of glass 
ionomer and composite-resin systems. J Esthet Dent 1994; 6: 22-44.

5. Leyhausen, G., Abtahi, M., Karbakhsch, M., Sapotnick,A., \& Geurtsen, W. Biocompatibility of various light-curing and one conventional glass-ionomer cement. Biomaterials, 1998;19 (6), 559-564.

6. Schmid-Schwap M., Franz A., Cytotoxicity of four categories of dental cements. Dent Mater 2009; 25: 360-8.

7. Koulaouzidou, E. A., Papazisis, K. T., Economides, N. A., Beltes, P., \& Kortsaris, A. H. (2005). Antiproliferative effect of mineral trioxide aggregate, zinc oxide-eugenol cement, and glass-ionomer cement against three fibroblastic cell lines. Journal of Endodontics, 2005; 31 (1), 44-46.

8. Schedle A., Franz A., Rausch-Fan X. H., Spittler A., Lucas T., Samorapoompichit P., Sperr W., Boltz-Nitulescu G. Cytotoxic effects of dental composites, adhesive substances, compomers and cements. Dent Mater 1998; 14: 429-40.

9. Sasanaluckit, P. A. K. R., Albustany, K. R., Doherty, P. J., \& Williams, D. F. (1993). Biocompatibility of glass ionomer cements. Biomaterials, 14 (12), 906-916.

10. Sidhu S., Schmalz G. The biocompatibility of glass ionómero cements materials. Status report. Am J Dentistry 2001; 14: 387-96.

11. Hatton P., Hurrell-Gillingham K., Brook I. Biocompatibility of glass-ionomer bone cements. J Dent 2006; 34: 598-601.

12. Brook I., Hatton P. Glass-ionomers: bioactive implant materials. Biomaterials 1998; 19: 565-71.

13. Giacomelli E., Gonçalves E., Mitsuo H., Belle R., Mayumi L. Development of glass ionomer cement modified with seashell powder as a scaffold material for bone formation. Rev Odonto Cienc 2011; 26: 40-4.
14. Giannoudis, P. V., Dinopoulos, H., \& Tsiridis, E. (2005). Bone substitutes: an update. Injury, 36 (3), S20-S27.

15. Sheets, J. L., Wilcox, C., \& Wilwerding, T. (2008). Cement Selection for Cement-Retained Crown Technique with Dental Implants. Journal of Prosthodontics, 17 (2), 92-96.

16. Shen C. Dental Cements. In: Anusavice KJ, editor. Phillips' Science of Dental Materials. 11st ed. Missouri USA: Saunders Elsevier; 2007. Pp. 474.

17. Øilo G. Biodegration of dental composite/glass ionomer cements. Adv Dent Res 1992; 6: 50-4.

18. Yli-Urpo, H., Vallittu, P. K., Närhi, T. O., Forsback, A. P., \& Väkiparta, M. Release of silica, calcium, phosphorus, and fluoride from glass ionomer cement containing bioactive glass. Journal of biomaterials applications, 2004; 19: 5-20.

19. Oliva A., Della Ragione F., Salerno A., Riccio V., Tartaro G., Cozzolino A., D’Amato S., Pontoni G., Zappia V. Biocompatibility studies on glass ionomer cements by primary cultures of human osteoblasts. Biomaterials 1996; 17: 1351-6.

20. Sjögren S., Sjögren G., Effects of glass ionomers and dental resin composites on viability of b-cells and insulin release in isolated islets of Langerhans. Biomaterials 2003; $24: 37416$.

21. Machaca K., Ca 2+ signaling, genes and cell cycle. Cell calcium 2010; 48: 243-50.

22. Lönnroth E., Einar J. Cytotoxicity of dental glass ionomers evaluated using dimethylthiazol diphenyltetrazolium and neutral red tests. Acta Odontol Scand 2001; 59: 34-9.

23. Nicholson J., Czarnecka B., Review Paper: Role of aluminum in Glass-ionomer dental cements and its biological effects J. Biomaterials Applicate. 2009; 24: 293-308. 